УДК 616. 314. 17 - $018.4-02: 616$-056. 52] - 053. 2

DOI 10.11603/2311-9624.2017.3.8026

(С). І. Лебідь, К. М. Дуда

ДВНЗ «Тернопільський державний медичний університет імені I. Я. Горбачевського»

\title{
Особливості клінічних проявів ураження тканин пародонта у підлітків на тлі аліментарно-конституціонального ожиріння
}

Резюме. У статті представлено результати клінічного обстеження тканин пародонта у підлітків на тлі аліментарно-конституціонального ожиріння.

Мета дослідження - вивчити особливості перебігу захворювань тканини пародонта за клінічними показниками в осіб з аліментарно-конституціональним ожирінням.

Матеріали і методи. У результаті проведеного обстеження 95 підлітків віком 16-18 років було включено для вивчення особливостей перебігу запальних захворювань тканин пародонта (76 осіб із аліментарно-конституціональним ожирінням (АКО) та 19 підлітків із гармонійним фізичним розвитком). Для уточнення діагнозу надмірної маси тіла визначали масу та ріст пацієнта, а також вимірювали окружність талії та стегон. Надалі розрахували індекс маси тіла (IMT) як співвідношення маси тіла в кг до квадрата величини росту в $\mathbf{M}^{2}$. Діагноз надмірної маси тіла підтверджували при IMT менше 30 кг/м². Оцінку стану тканин пародонта здійснювали за суб’єктивними й об'єктивними критеріями (клінічні показники, індексна оцінка). Для верифікації патологічного процесу в пародонті використовували класифікацію М. Ф. Данилевського (1994). Стан тканин пародонта описували за допомогою традиційної індексної оцінки. Статистичну обробку результатів проводили з використанням загальноприйнятих методів варіаційної статистики за допомогою персонального комп’ютера 3 використанням пакета статистичних програм Statistica 8,0 (Statsoft, США). Рівень вірогідності оцінювали на рівні $95 \%(\mathrm{p}<0,05)$ з використанням t-критерію Стьюдента.

Висновки. Клінічні показники стану тканин пародонта на тлі аліментарно-конституціонального ожиріння (індекси Федорова-Володкіної, Green-Vermillion, Sillness-Loe, показник CPITN) значно погіршуються, порівняно з відповідними показниками у контрольній групі підлітків без АКО, що вказує на вплив аліментарно-конституціонального ожиріння на клінічний перебіг, вираження та тяжкість запального процесу і доцільність проведення своєчасної та ефективної фармакотерапії.

Ключові слова: аліментарно-конституціональне ожиріння; захворювання пародонта.

(с). И. Лебидь, К. М. Дуда

ГВУз «Тернопольский государственный медицинский университет имени И. Я. Горбачевского»

\section{Особенности клинических проявлений поражения тканей пародонта у подростков на фоне алиментарно-конституционального ожирения}

Резюме. В статье представлены результаты клинического обследования тканей пародонта у подростков на фоне алиментарно-конституционального ожирения.

Цель исследования - выучить особенности течения заболеваний ткани пародонта по клиническим показаниям у лиц с алиментарно-конституциональным ожирением.

Материалы и методы. В результате проведенного обследования 95 подростков в возрасте 16-18 лет были включены для изучения особенностей течения воспалительных заболеваний тканей пародонта (76 лиц с алиментарно-конституциональным ожирением (АКО) и 19 подростков с гармоничным физическим развитием). Для уточнения диагноза чрезмерной массы тела определяли вес и рост пациента, а также измеряли окружность талии и бедер. В дальнейшем рассчитали индекс массы тела (ИМТ) как соотношение массы тела в кг к квадрату величины роста в м $^{2}$. Диагноз избыточной массы тела подтверждали при ИМТ менее 30 кг/м². Оценку состояния тканей пародонта осуществляли по субъективным и объективным критериям (клинические показатели, индексная оценка). Для верификации патологического процесса в пародонте использовали классификацию Н. Ф. Данилевского (1994). Состояние тканей пародонта описывали с помощью традиционной индексной оценки. Статистическую обработку результатов проводили с использованием общепринятых методов вариаци- 


\title{
Дитяча стоматологія
}

онной статистики с помощью персонального компьютера с использованием пакета статистических программ Statistica 8,0 (Statsoft, США). Уровень достоверности оценивали на уровне $95 \%(\mathrm{p}<0,05)$ с использованием t-критерия Стьюдента.

Выводы. Клинические показатели состояния тканей пародонта на фоне алиментарно-конституционального ожирения (индексы Федорова-Володкиной, Green-Vermillion, Sillness-Loe, показатель (PITN) значительно ухудшаются, по сравнению с соответствующими показателями в контрольной группе подростков без АКО, что указывает на влияние алиментарно-конституционального ожирения на клиническое течение, выраженность и тяжесть воспалительного процесса и целесообразность проведения своевременной и эффективной фармакотерапии.

Ключевые слова: алиментарно-констутиционное ожирение; заболевания пародонта.

\author{
C) O. I. Lebid, K. M. Duda
}

I. Horbachevsky Ternopil State Medical University

\section{Features of clinical manifestations of perodontal tissue damage in adolescents on the area of alimentary-constitutional obesity}

\begin{abstract}
Summary. The article presents the results of clinical examination of periodontal tissues in adolescents against the background of alimentary-constitutional obesity.

The aim of the study - to investigate the features of the course of diseases of the periodontal tissue according to clinical indices in persons with alimentary-constitutional obesity.

Materials and Methods. As a result of the survey, 95 adolescents aged 16-18 years old were included to study the features of the course of inflammatory diseases of periodontal tissues in adolescents with alimentary-constitutional obesity 76 adolescents and 19 adolescents with harmonious physical development. To clarify the diagnosis, «excessive body weight» was determined by weight and height of the patient, and measured the circumference of the waist and hips. In the future, the body mass index (BMI) was calculated as the ratio of body weight in kg to square of growth in $\mathrm{m} 2$. Diagnosis of excess body weight was confirmed with BMI less than $30 \mathrm{~kg} / \mathrm{m} 2$. The evaluation of the condition of periodontal tissues was carried out according to subjective and objective criteria (clinical parameters, index score). For the verification of the pathological process in the periodontium, the classification of M. F. Danilevskyi (1994) was used. The state of periodontal tissues was described using a traditional index score. Statistical processing of the results was carried out using commonly used methods of variation statistics with a help of personal computer using a statistical software package «Statistica 8.0» («Statsoft», USA). The probability level was estimated at $95 \%(\mathrm{p}<0.05)$ using Student's t criterion.

Conclusions. Consequently, the clinical indicators of the state of periodontal tissues in the context of alimentaryconstitutional obesity (Fedorov-Volodkin's index, Green-Vermillion index, Sillness-Loe index, CPITN index) significantly deteriorate compared with the corresponding indicators in the control group of adolescents without AKO, indicating the effect of alimentary-constitutional obesity on the clinical course, the severity and severity of the inflammatory process and the feasibility of timely and effective pharmacotherapy.
\end{abstract}

Key words: alimentary-constitutional obesity; periodontal disease.

Вступ. Поширеність захворювань тканин пародонта у людини, за даними ВОО3, є шостим серед розповсюджень захворювань [16]. На даний момент доведено, що основним етіологічним чинником розвитку запалення в пародонті є якісні та кількісні зміни мікрофлори порожнини рота, зокрема активація пародонтопатогенних мікроорганізмів [9]. Разом $з$ тим, резистентність тканин пародонта до патогенної дії мікроорганізмів визначають системні фактори. Очевидно, що у пацієнтів із тяжкою супутньою патологією ризик виникнення та ступінь тяжкості пародонтиту значно більші. До захворювань, що значною мірою впливають на розвиток та перебіг пародонтиту, відносять і ожиріння [17].

Виникнення захворювань пародонта у дітей та підлітків до останнього часу пов’язують переважно із загальною патологією організму, адже загальносоматичні захворювання проходять на тлі гуморальної та клітинної недостатності, а також на фоні змін обмінних процесів в організмі, що, у свою чергу, спричиняє погіршення стану тканин пародонта [2, 7, 9]. Вивчення змін в організмі, які розвиваються при соматичних захворюваннях, свідчать, що одні з перших проявів цих патологій визначаються в органах та системах порожнини рота, які пояснюються 
наявністю тісних ембріональних та функціональних зв'язків 3 нервовою, кровотворною, ендокринною системами та органами шлунково-кишкового тракту (ШКТ) [3, 4, 6, 12].

У літературі з'явилися роботи, в яких автори вказують на вплив ожиріння та надмірної маси тіла у дітей та підлітків із захворюваннями тканин пародонта [5, 10, 11]. Відомо, що у підлітковому періоді розвивається низка дефіцитних станів в організмі, тобто виникають умови для формування інфекційно-запальних патологічних процесів, у тому числі й у тканинах пародонта [13-15].

Вітчизняні та зарубіжні педіатри відзначають, що з кожним роком надмірна маса тіла та ожиріння серед дітей та підлітків зростає приблизно на $1 \%[1,16]$.

У зв'язку з цим, у своєму дослідженні ми визнали за доцільне з'ясувати наявність взаємозв'язку клінічних проявів захворювань тканин пародонта із антропометричними показниками, що описують наявність надмірної маси тіла. На наш погляд, подібного роду спостереження дозволять створити коректний підхід у лікуванні та профілактиці захворювань тканин пародонта серед контингенту хворих, що вивчається.

Метою дослідження було вивчити особливості перебігу захворювань тканини пародонта за клінічними показниками в осіб з аліментарно-конституціональним ожирінням (АКО).

Матеріали і методи. У результаті проведеного обстеження 95 підлітків віком 16-18 років було включено для вивчення особливостей перебігу запальних захворювань тканин пародонта (76 осіб з АКО та 19 підлітків із гармонійним фізичним розвитком).

Для уточнення діагнозу надмірної маси тіла визначали масу та ріст пацієнта, а також вимірювали окружність талії та стегон. Надалі розрахували індекс маси тіла (IMT) як співвідношення маси тіла в кг до квадрата величини росту в м $^{2}$. Діагноз надмірної маси тіла підтверджували при IMT менше 30 кг/ $\mathbf{M}^{2}$.

Оцінку стану тканин пародонта здійснювали за суб’єктивними й об’єктивними критеріями (клінічні показники, індексна оцінка). Для верифікації патологічного процесу в пародонті використовували класифікацію М. Ф. Данилевського (1994). Стан тканин пародонта описували за допомогою традиційної індексної оцінки [8].

Статистичну обробку результатів проводили 3 використанням загальноприйнятих методів варіаційної статистики за допомогою персонального комп'ютера 3 використанням пакета статистичних програм Statistica 8,0 (Statsoft, США). Рівень вірогідності оцінювали на рівні $95 \%(p<0,05) 3$ використанням t-критерію Стьюдента (О. Ю. Реброва, 2002).

Результати досліджень та їх обговорення. У результаті проведеного анкетування та обстеження 95 підлітків віком 16-18 років було встановлено наступне. За даними антропометричного дослідження, у 19 підлітків (20 \%) виявлено надмірну масу тіла, а ожиріння I ступеня констатовано у 53 (55,8 \%), ожиріння II ступеня - відповідно у 23 (24,2 \%), що підтверджувалося визначенням IMT (табл. 1), і збігалося з результатами анкетування щодо нераціонального харчування і малорухливого способу життя. Так, 51,2 \% респондентів харчувалися у закладах швидкого харчування, систематично споживали солодкі газовані та енергетичні напої, вели малорухливий спосіб життя. Анкетування показало, що 17,3 \% із числа опитаних дівчат та 22,4 \% хлопців періодично вживали слабоалкогольні напої.

Ми провели дослідження з метою встановити взаємозв'язок між станом тканин пародонта та наявністю аліментарно-конституціонального ожиріння в обстежених підлітків шляхом оцінки стану гігієни ротової порожнини.

Відомо, що цей гігієнічний індекс слугує для оцінки гігієни порожнини рота із позицій лише зубного нальоту. Результати, які ми отримали, показали, що серед 19 осіб контрольної групи добрий гігієнічний стан - 0,37£0,05; p<0,05 визначається у 7 або 36,8 \% підлітків,

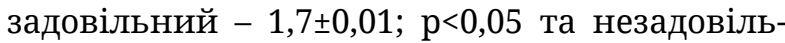

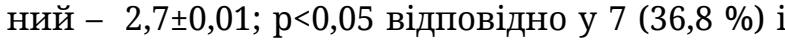
5 (26,4 \%), проте у цій групі не було виявлено підлітків із високими показниками індексу

таблищя 1. Показники індексу маси тіла в обстежених підлітків $(\mathrm{M} \pm \mathrm{m})$

\begin{tabular}{|l|c|}
\hline \multicolumn{1}{|c|}{ Категорія підлітків } & Індекс маси тіла \\
\hline Контрольна група (n=19) & $18,50 \pm 0,01$ \\
\hline Надмірна маса тіла (n=19) & $25,41 \pm 0,05$ \\
\hline Аліментарно-конституціональне ожиріння I ступеня (n=53) & $31,60 \pm 0,07$ \\
\hline Аліментарно-конституціональне ожиріння II ступеня (n=23) & $35,80 \pm 0,03$ \\
\hline
\end{tabular}




\section{Дитяча стоматологія}

Федорова-Володкіної, що відповідає поганому стану гігієни порожнини рота. Як видно із наведених даних, у підлітків з аліментарноконституціональним ожирінням переважно визначали незадовільний та поганий стан гігієни порожнин рота, на що вказують значен- ня індексу Федорова-Володкіної відповідно у $(2,36 \pm 0,017 ; p<0,05)$ i $(2,7 \pm 0,01 ; p<0,05)$ бала.

Ми провели визначення індексу GreenVermillion (IGV), що дозволяє оцінити не лише зубний наліт, але й зубний камінь. Результати досліджень представлено у таблиці 2.

таблищя 2. Стан гігієни порожнини рота за індексом Green-Vermillion у підлітків

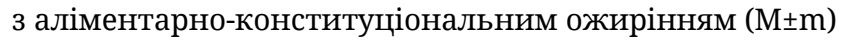

\begin{tabular}{|l|c|c|c|}
\hline \multirow{2}{*}{ Категорія дітей } & \multicolumn{2}{|c|}{ Показник індексу Green-Vermillion, бали } \\
\cline { 2 - 4 } & добрий & середній & поганий \\
\hline Здорові підлітки (n=19) & $0,14 \pm 0,02$ & $0,38 \pm 0,05$ & $0,60 \pm 0,01$ \\
\hline $\begin{array}{l}\text { Підлітки з аліментарно-конституціональним } \\
\text { ожирінням (n=76) }\end{array}$ & - & $1,24 \pm 0,01^{*}$ & $2,1 \pm 0,02^{*}$ \\
\hline
\end{tabular}

Примітка. * - відносно показника у групі здорових підлітків (p<0,05).

Виявлені зміни індексу Green-Vermillion відповідають змінам індексу Федорова-Володкіної. Серед контрольної групи добрий стан гігієни порожнини рота за індексом IGV спостерігався у 7 пацієнтів або 36,8 \%, середній і поганий відповідно у 8 (42,1 \%) і в 4 (21,1 \%). При цьому індекс Green-Vermillion у підлітків 3 поганим станом порожнини рота зріс у 4,3 раза порівняно з особами із доброю гігієною порожини рота. Водночас, у підлітків на тлі АКО за індексом IGV встановлено середній та поганий стани гігієни рота відповідно у $51(67,1 \%)$ i 25 (32,9 \%) осіб. Варто зазначити, що цей показник на тлі АКО вірогідно зріс, порівняно з контрольною групою (здорові підлітки), при середньому стані гігієни рота у 3,26 раза, а при поганому - в 3,5 раза, що вказує на суттєвий вплив аліментарно-конституціонального ожиріння на погіршення стану гігієни порожнини рота за відповідним індексом.

Для характеристики ступеня запального процесу ясен вивчали індекс Silness-Loe (ISL), результати дослідження наведені у таблиці 3.

У підлітків контрольної групи встановлено наявність гінгівіту різного ступеня тяжко- сті. Так, легкий ступінь гінгівіту виявлено у 7 або 36,8 \%, середній - 8 (42,1 \%) і тяжкий у 4 (21,1 \%). Ці дані підтверджуються зростанням ISL у підлітків із гінгівітом середньої тяжкості в 3,93 раза, порівняно з пацієнтами із гінгівітом легкого ступеня, а у пацієнтів із тяжким ступенем гінгівіту - у 5,43 раза. Ми встановили, що у підлітків з АКО легкий ступінь гінгівіту спостерігали у 23 або 30,3 \%, середньої тяжкості - у 40 (52,6 \%) і тяжкий ступінь гінгівіту - в 13 (17,1 \%). При цьому в підлітків на тлі AКО показник ISL був у 4 рази більший, порівняно з контрольною групою $(p<0,05)$, відповідно у 3 рази вищим він був ( $<<0,001)$ при середньому ступені тяжкості, а при тяжкому гінгівіті у 3,2 раза перевищував відповідний показник у здорових підлітків. Ці дані вказують на те, що наявність аліментарно-конституціонального ожиріння в осіб сприяє більш вираженому розвитку запального процесу в тканинах пародонта, що проявляється тяжчим ступенем гінгівіту.

В0О3 при епідеміологічних обстеженнях захворювань пародонта рекомендує використовувати пародонтальний індекс CPITN

таблищя 3. Стан запального процесу в обстежених підліткв за індексом Sillness-Loe (Mェm)

\begin{tabular}{|l|c|c|c|}
\hline \multirow{2}{*}{\multicolumn{1}{|c|}{ Категорія підлітків }} & \multicolumn{3}{|c|}{ Показник індексу Sillness-Lое, бали } \\
\cline { 2 - 4 } & легкий гінгівіт & $\begin{array}{c}\text { гінгівіт середньої } \\
\text { тяжкості }\end{array}$ & $\begin{array}{c}\text { гінгівіт тяжкого } \\
\text { ступеня }\end{array}$ \\
\hline $\begin{array}{l}\text { 3дорові підлітки } \\
(\mathrm{n}=19)\end{array}$ & $0,14 \pm 0,08$ & $0,55 \pm 0,08$ & $0,76 \pm 0,01$ \\
\hline $\begin{array}{l}\text { Підлітки з аліментарно-конституціональним } \\
\text { ожирінням (n=76) }\end{array}$ & $0,56 \pm 0,05^{*}$ & $1,67 \pm 0,01^{*}$ & $2,42 \pm 0,09$ \\
\hline
\end{tabular}

Примітка. * - відносно показника у групі здорових дітей (p<0,05). 
(Community Periodontal Index of Treatment Needs) - індекс потреби в лікуванні захворювань пародонта. Аналіз результатів, наведених у таблиці 4, показав, що у контрольній групі не було виявлено кровоточивості після зондування, зонд не проникав у ясенну кишеню, не було глибоких кишень. Це свідчить про те, що дана категорія пацієнтів не потребує фармакотерапевтичного лікування, а їм рекомендується професійна гігієна ротової порожнини.

Проте у підлітків із гінгівітом на тлі АКО усі ці ознаки були наявними, зокрема кровоточивість після зондування у 76 обстежених підлітків на тлі АКО виявлялась у 63,2 \%, при зондуванні ясенної кишені зонд занурювався у 31,6 \%, а наявність кишені глибиною до 4 мм

\section{Список літератури}

1. Аверьянов А. П. Нейровегетативные нарушения у детей с ожирением в период пубертата и их коррекция / А. П. Аверьянов, Н. В. Болотова // Педиатрия : Журн. им. Г. Н. Сперанского. - 2009. - Т. 87, № 3. C. 47-52.

2. Белоклицкая Г. Ф. Клинические формы генерализованного пародонтита и их значение для его дифференцированой терапии / Г. Ф. Белоклицкая // Вестник стоматологии. - 1998. - № 3. - С. 16-20.

3. Белоусов Ю. В. Функцыональные заболевания пищеварительной системи у детей : монография / Ю. В. Белоусов, О. Ю. Белоусов. - Х. : ИД «ИНЖЭК», 2005. -256 c.

4. Вишняк Г. Н. Пародонтоз у детей и подростков, отягощенный общей патологией / Г. Н. Вишняк : материалы научно-практической конференции по вопросам стоматологии детского возроста. - М., 1969. - C. 132-135.

5. Вознесенская Т. Г. Ожирение / Т. Г. Вознесенская // Междунар. мед. журнал. - 2000. - № 1. - С. 90-93.

6. Гударьян А. А. Частота и особенности клинического проявления генерализованого пародонтита при различных компонентах метаболичного синдрома / А. А. Гударьян // Вісник стоматології. - 2003. № 1. - С. 20-23.

7. Данилевский Н. Ф. Систематика болезней пародонта / Н. Ф. Данилевский // Вісник стоматології. 1994. - № 1. - C. 17-21.

8. Терапевтична стоматологія. Захворювання пародонта / [А. В. Борисенко и др.]. - Медицина, 2008. T. 3. -614 c.

\section{References}

1. Averyanov, A.P. \& Bolotova, N.V. (2009). Neyrovegetativni narusheniya $u$ detey s ozhireniyem $\mathrm{v}$ period pubertata i ikh korektsiya [Neurovegetative disorders in children with obesity during puberty and their correction]. Pediatriya: zhurnal imeni G.N. Speranskiy - Journal named after G.N. Speranskiy, 87 (3), 47-52 [in Russian]. виявили лише у 5,3 \%. Це вказує на необхідність застосування лікувальних середників для поліпшення перебігу та прогнозу захворювання.

Висновки. Клінічні показники стану тканин пародонта на тлі аліментарно-конституційного ожиріння (індекси Федорова-Володкіної, Green-Vermillion, Sillness-Loe, показник CPITN) значно погіршуються, порівняно з відповідними показниками у контрольній групі підлітків без АКО, що вказує на вплив аліментарноконституціонального ожиріння на клінічний перебіг, вираження та тяжкість запального процесу і доцільність проведення своєчасної та ефективної фармакотерапії.

9. Заболотний Т. Д. Генералізований пародонтит / А. В. Борисенко, А. В. Марков, І. В. Шилівський. Львів: ГалДент, 2011. - 240 с.

10. Клинические проявления ожирения у детей / Е. В. Павловская, А. Г. Сурков, Т. В. Стракова, А. И. Зубакович // ПАГ. - 2009. - Т. 71, № 5. - С. 50-51.

11. Перова М. Д. Ткани пародонта: норма, патология, пути восстановления / М. Д. Перова. - М. : Триада Лтд., 2005. - С. 77-104.

12. Скрипников П. Н. Определение плотности кости при пародонтите / Н. П. Ярынич-Бучинская, В. К. Югов, Л. Я. Богашова // Український стоматологічний альманах. - 2007. - № 5. - С. 42-45.

13. Савичук О. В. Сучасні особливості стану тканин пародонту у дітей / О. В. Савичук, Л. О. Тимофєєва // Ліки України. - 2010. - № 3. - С. 54-56.

14. Makoto O. Effects stzreptozotocin-induced diabetes in neonatal rats with naturalli occurring gingivitis / O. Makoto, S. Mitsuko // Departament of Pharmacology. 2003. - Vol. 37, № 1. - P. 13-19.

15. Ogden C. L. Prevalence and trends in overweight among US children and adolescents / C. L. Ogden, K. M. Flegal, M. D. Carroll // JAMA. - 2002. - Vol. 288, № 14. - P. 1728-1732.

16. World Health Organization (WHO). Бюллетень Bceмирной организации здарохранения. - 2015. - № 93. C. 594-595 [Электронный ресурс]. - Режим доступа: http://www.who.int/bulletin/volumes/93/9/15-020915/ru/. 17. Keller A. Association between periodontal disease and overweight and obesity: a systematic review / A. Keller, J.F.Rohde, K. Raymond, B.L. Heitmann // Journal of Periodontology. - 2015. -Vol. 86, N 6. -P.766-776.

2. Beloklitskaya, G.F. (1998). Klinicheskie formy generalizirovanogo parodontita i ikh znachenie dlya differentsiyirovanoy terapii [Clinical forms of generalized periodontitis and their significance for its differentiated therapies]. Vestnik stomatologii - Journal of Dentistry, 3, 16-20 [in Russian]. 


\section{Дитяча стоматологія}

3. Belousov, Yu.V. \& Belousov, O.Yu. (2005). Funktsionalnye zabolevaniya pishchevaritelnoy sistemy $u$ detey: Monografiya [Functional diseases of the digestive system in children: Monograph]. Kharkiv: ID "INZhEK" [in Russian].

4. Vushniak H.N. (1969). Paradontoz u detey i podrostkov otyagoshchonnyy obshchey patologiyey [Periodontitis in children and adolescents, burdened with general pathology] Materialy of naukovoprakticheskoy konferentsyi po voprosam stomatologii detskogo vozrasta - Materials of the Scientific-Practical Conference on the Issues of Stomatologists of Children's Growth. (pp. 132-135). Moscow [in Russian].

5. Voznesenskaya, T.G. (2000). Ozhirenie [Obesity]. Mezdunarodnyy meditsinskiy zhurnal - International Medical Journal (1), 90-93 [in Russian].

6. Gudaryan, A.A. (2003). Chastota i osobennosti klinicheskogo generalizovanogo parodontita pri razlichnikh komponentax metabolicheskogo sindroma [Frequency and features of the clinical manifestation of generalized periodontitis with various components of the metabolic syndrome]. Visnyk stomatologii - Journal of Dentistry (1), 20-23 [in Russian].

7. Danylevskiy, N.F. (1994). Systematika bolezney paradonta [Systematics of periodontal diseases]. Visnyk stomatologii - Journal of Dentistry, 1, 20-23 [in Russian]. 8. Borysenko, A.V. (2008). Terapevtychna stomatolohiia. Zakhvoriuvannia parodonta. Tom 3. [Therapeutic dentistry. Periodontal disease. Volume 3]. Kyiv: Medytsyna [in Ukrainian].

9. Zabolotnyi, T.D., Markov, A.V., \& Shylivkyi, I.V. (2011). Henaralozovanyi parodontyt [Generalized periodontitis]. Lviv: HalDent [in Ukrainian].
10. Pavlovskaya, E.V., Surkov, A.G., Strakova, T.V., \& Zubakovich, A.I. (2009). Klinicheskie proyavleniya ozhyreniya $u$ detey [Clinical manifestations of obesity in children]. PAG, 71 (5), 50-51 [in Russian].

11. Perova, M.D. (2005). Tkani parodonta: norma, patologiya, puti vostonovleniya [Periodontal tissues: norm, pathology, ways of recovery]. Moscow: Triada Ltd [in Russian].

12. Skrypnikov, P.N., Yarynich-Buchinskaya, N.P., Yugov, V.K., \& Bogashova, L.Ya. (2007). Opredilenie plotnosti kosti pri parodontite [Determination of bone density in periodontitis]. Ukrainskyi stomatolohichnyi almanakh - Ukrainian Dental Almanac (5), 42-45 [in Russian].

13. Savychuk, O.V., \& Tymofieieva, L.O. (2010). Sychasni osoblyvosti stanu tkanyn parodonta u ditei [Modern features of the condition of periodontal tissues in children]. Liky Ukrainy - Medicines of Ukraine (3), 54-56 [in Ukrainian].

14. Makoto, O., \& Mitsuko, S. (2003). Effects stzreptozotocin-induced diabetes in neonatal rats with naturalli occurring gingivitis. Departament of Pharmacologi., 37 (1), 13-19.

15. Ogden, C.L., Flegal, K.M., \& Carroll, M.D. (2002). Prevalence and trends in overweight among US children and adolescents. JAMA, 288 (14), 1728-1732.

16. World Health Organization (WHO). (2015). Byuleten Vsemirnoy organizatsii zdravokhraneniya - Bulletin of World Organization of Public Health, 93, 594-595 [Electronic resource]. - Retrieved from: http://www.who. int/bulletin/volumes/93/9/15-020915/ru/ [in Russian].

17. Keller, A., Rohde, J.F., Raymond, K., \& Heitmann, B.L. (2015). Association between periodontal disease and overweight and obesity: a systematic review. Journal of Periodontology, 86 (6), 766-776. 